\title{
Youth Perceptions about Sundanese Food Graphic Video as Sundanese Food Education Media
}

\author{
Aurora Paramita Siswanto, Cica Yulia*, Elis Endang Nikmawati \\ Study Program of Culinary Education, Department of Home Economics \\ Universitas Pendidikan Indonesia \\ Bandung, Indonesia \\ *cicayulia@upi.edu, auroraparamitha@student.upi.edu, elisendang@upi.edu
}

\begin{abstract}
This research is motivated by the low knowledge of adolescents about traditional food, so that educational media is made in the form of graphic video and the perceptions of adolescents towards the graphic video of Sundanese food that not yet known. This study aims to analyse adolescent perceptions about Sundanese food graphic video as a Sundanese food education medium. This research is a descriptive study with data collection techniques using a questionnaire distributed online by considering the current situation and conditions of Covid-19 pandemic that does not allow researchers to take data directly. The subjects in this study were adolescents from the Department of Family Welfare Education batch 2019, consisting of Culinary Education Program, Fashion Design Education Program, and Family Welfare Education Program, totalling 63 people. The sampling technique used was cluster random sampling. The data processing technique uses a Likert scale with data analysis techniques using descriptive analysis which is expressed in the form of percentage. The results showed that most of the respondents $(76.9 \%)$ had a good perception towards the capability of Sundanese food graphic video based on 4 perceptual aspects, namely attention, needs, satisfaction and visualization. Most of the respondents $(77 \%)$ have a good perception towards the attention aspect. More than half of respondents $(\mathbf{7 2 . 6 \%})$ have a good perception towards the needs of video aspects. Most of the respondents $(80.65 \%)$ have a good perception towards the video satisfaction aspect. Most of the respondents $(\mathbf{7 7 . 7 \%})$ have a good perception towards the video visualization aspect.
\end{abstract}

Keywords-perception, Sundanese food, adolescent, attention, needs, satisfaction, visualization

\section{INTRODUCTION}

Sundanese food is a food consumed by the people of West Java, prepared from recipes known to the people of West Java. The ingredients are obtained from local sources and produced from the surrounding agricultural businesses and have a taste that suits the tastes of the Sundanese people [1]. Adolescent's knowledge of traditional food is low. This is due to the lack of information about the traditional food that they got [2]. Student's eating knowledge is influenced by many factors such as the home environment, environmental accessibility education, the availability of food providers, and the social environment. The lack of recognition and appreciation of the traditions and history of the culinary culture archipelago is also a major factor in the lack of public knowledge about traditional food [3]. Traditional food is one of the media to preserve the culture which is the national identity. Therefore, there is an obligation for the community to maintain and preserve the national identity. The role of society is very important in preserving culture, including the young generation who will become the nation's successor. Therefore, education is needed to increase public knowledge about traditional food.

In line with the development of information technology, educational institutions have begun to innovate learning media. One of the media commonly used as educational media is graphic video. Graphic video is believed to be an effective medium for delivering information [4]. Graphic video is a medium for recording a moment or event that is summarized in the history of images and sounds that we can enjoy later, either as a prohibition or as a study material to learn what has happened or has happened [5].

Sundanese Food Graphic video is one of the videos designed and developed by a team of research to transfer knowledge and information on Sundanese food to all groups, especially teenagers. This video contains important information from traditional foods. Therefore, it is hoped that this video can help to increase the knowledge of teenagers about traditional food, especially Sundanese food.

To see the extent of adolescent perception, especially students of Family Welfare Education UPI Department batch 2019, towards Sundanese food educational videos, it is needed a study that examines teenagers' perceptions towards Sundanese food educational videos as a traditional food information medium, so that it can be used as a reference for improvement. Perception is a person's response to an object with the help of the senses. The adolescent's perception of Sundanese food videos as educational media is carried out by approaching the systematic message conveyed by Sundanese food educational videos [6]. Formulate a systematic arrangement of messages based on ANSVA (Attention, Needs, Satisfaction, Visualization and Action). This study aims to analyse adolescent perceptions about Sundanese food graphic video as a Sundanese food education medium. 


\section{RESEARCH METHODS}

This research is a descriptive study with a quantitative approach to Family Welfare Education UPI student batch 2019 who have used Sundanese food educational videos. The data collection technique used is through questionnaire. This questionnaire method used to obtain written answers was in accordance with the questions the researcher asked. The questionnaire is a data collection technique which is done by giving a set of questions or written statements to the respondent to be answered [7].

Indicators used to measure the feasibility of Sundanese food educational videos include: (1) Attention, namely the ability of videos to show teaching materials about Sundanese food, (2) Needs, namely the ability of videos to show problems faced in an effort to increase knowledge of Sundanese food in adolescents, (3) ) Satisfaction, namely the ability of videos to provide an explanation of the importance of knowledge of Sundanese food in adolescents, and (4) Visualization, namely the ability of videos to provide clear and interesting visualizations.

The population in this study were students of Family Welfare Education UPI batch 2019. Samples were taken using cluster random sampling technique and obtained from calculations using the Slovin formula as many as 63 students. The data used in this study are primary data obtained through a questionnaire on the graphic video of Sundanese food. The data obtained were analysed descriptively analytically using a Likert scale.

\section{RESUlTS AND DisCUSSION}

Graphic video is believed as an effective medium for delivering information [4]. Graphic video educational media designed by a team of research is an educational video of Sundanese food for teenagers. Therefore, this media can be used as a medium that can help in increasing the knowledge of Sundanese food of adolescents in this modern era. In this study, Sundanese food educational videos have been launched to Family Welfare Education UPI students batch 2019 since July 2020. A media, in this case is a video, can be said as appropriate for communication / information medium if the video contains several elements, namely attention, needs, satisfaction and visualization element. The following are the results of a study on adolescent perceptions about the Sundanese food graphic video as a media for Sundanese food education, by looking at the respondents' perceptions of attention, needs, satisfaction and visualization elements in the Sundanese food educational video.

\section{A. Youth Perceptions of Attention Aspect on Sundanese Food Graphic Video}

Adolescent perceptions of attention aspect on Sundanese food graphic video is the teenagers' impression towards the ability of media to show interesting teaching materials for them. This is measured by the ability of the video to provide an overview of Sundanese food, starting from its definition, origin, history, raw materials, and how to make the types of Sundanese food that are shown in the graphic video. The following are the results of the frequency distribution of adolescent perceptions on the attention aspect of Sundanese food educational video.

Table 1 shows that the majority $(77 \%)$ have a good impression towards the media's ability to show interesting teaching materials for adolescents. This means that as an educational medium, the graphic video of Sundanese food has been able to provide an overview of Sundanese food, starting from its understanding, origins, history, raw materials, and ways of making Sundanese food which are shown in the Sundanese food educational video comprehensively.

TABLE I. YOUTH PERCEPTIONS OF ATTENTION ASPECT ON SUNDANESE FOOD GRAPHIC VIDEO

\begin{tabular}{|c|l|c|c|}
\hline No. & \multicolumn{1}{|c|}{ Statement } & Percentage & Category \\
\hline 1. & $\begin{array}{l}\text { The material about the meaning of } \\
\text { Sundanese food in this video is clear. }\end{array}$ & $81 \%$ & Good \\
\hline 2. & $\begin{array}{l}\text { The material about the origin of } \\
\text { Sundanese food in this video is clear. }\end{array}$ & $80 \%$ & Good \\
\hline 3. & $\begin{array}{l}\text { The material about the history of } \\
\text { Sundanese food in this video is clear. }\end{array}$ & $76.5 \%$ & Good \\
\hline 4. & $\begin{array}{l}\text { The material about the raw materials } \\
\text { for making Sundanese food in this } \\
\text { video is clear. }\end{array}$ & $82 \%$ & Good \\
\hline 5. & $\begin{array}{l}\text { The material on how to make } \\
\text { Sundanese food in this video is clear }\end{array}$ & $64 \%$ & Sufficient \\
\hline 6. & $\begin{array}{l}\text { I find it easier and better to } \\
\text { understand about Sundanese food } \\
\text { material if it is presented in the form } \\
\text { of video like in this video }\end{array}$ & $\begin{array}{c}\text { Toral } \\
\text { Tource: Primary Data Analysis, 2020 }\end{array}$
\end{tabular}

\section{B. Youth Perceptions of Needs Aspect on Sundanese Food Graphic Video}

Adolescent perceptions of needs aspect on Sundanese food graphic video is the teenagers' impressions towards the ability of media to show the problems faced in an effort to increase their knowledge. This is measured by the ability of the video to provide an overview of the problems faced by adolescents related to knowledge of Sundanese food, starting from knowledge about the types of Sundanese food, history, basic ingredients, origin, and how to make the types of Sundanese food that are shown in the graphic videos. Following are the results of the frequency distribution of adolescents' perceptions towards needs aspects in Sundanese food educational video.

Table 2 shows that more than half of the respondents (72.6\%) have a good impression towards the media's ability to show the problems faced in an effort to increase adolescent knowledge. This means that as an educational medium, graphic video of Sundanese food has been able to provide a good picture of the problems faced by adolescents related to 
knowledge of Sundanese food, starting from knowledge of the types of Sundanese food, history, basic ingredients, origin, and how to make the types of Sundanese food shown in the Sundanese food video.

TABLE II. Youth Perceptions Of ATtENTION ASPECT ON SUNDANESE FOOD GRAPHIC VIDEO

\begin{tabular}{|c|l|c|c|}
\hline No. & \multicolumn{1}{|c|}{ Statement } & Percentage & Category \\
\hline 1. & $\begin{array}{l}\text { Knowledge of Sundanese food } \\
\text { types in the video. }\end{array}$ & $76 \%$ & Good \\
\hline 2. & $\begin{array}{l}\text { I already know the history of } \\
\text { Sundanese food presented in the } \\
\text { video }\end{array}$ & $60 \%$ & Sufficient \\
\hline 3. & $\begin{array}{l}\text { I already know the basic } \\
\text { ingredients for making } \\
\text { Sundanese food which are } \\
\text { presented in the video }\end{array}$ & $76 \%$ & Good \\
\hline 4. & $\begin{array}{l}\text { I already know the area of origin } \\
\text { of the Sundanese food presented } \\
\text { in the video }\end{array}$ & $75 \%$ & Sufficient \\
\hline 5. & $\begin{array}{l}\text { I already know how to make } \\
\text { Sundanese food which is } \\
\text { presented in the video }\end{array}$ & $76 \%$ & Good \\
\hline \multicolumn{2}{|c|}{ Total } & $363 \%: 5=$ & Sufficient \\
\hline \multicolumn{2}{|l|}{} & \multicolumn{2}{|c|}{ Source: Primary Data Analysis, 2020 }
\end{tabular}

\section{Youth Perceptions of Satisfaction Aspect on Sundanese Food Graphic Video}

Adolescent's perception of satisfaction aspect on Sundanese food graphic video is the teenagers' impression on the ability of video in providing explanation about the importance of Sundanese food knowledge to them. Following are the results of the frequency distribution of adolescents' perceptions towards satisfaction aspects in Sundanese food educational video.

TABLE III. YOUTH PERCEPTIONS OF SATISFACTION ASPECT ON SUNDANESE FOOD GRAPHIC VIDEO

\begin{tabular}{|c|c|c|c|}
\hline No. & Statement & Percentage & Category \\
\hline 1. & $\begin{array}{l}\text { I think this educational video on } \\
\text { Sundanese food is very important } \\
\text { to be learned }\end{array}$ & $85 \%$ & Good \\
\hline 2. & $\begin{array}{l}\text { I think this Sundanese food } \\
\text { educational video gave me new } \\
\text { knowledge about Sundanese food }\end{array}$ & $84 \%$ & Good \\
\hline 3. & $\begin{array}{l}\text { I think this educational video on } \\
\text { Sundanese food makes me more } \\
\text { interested in learning about } \\
\text { Sundanese food }\end{array}$ & $79 \%$ & Good \\
\hline 4. & $\begin{array}{l}\text { I think this video Sundanese food } \\
\text { makes me want to develop the } \\
\text { culture through food }\end{array}$ & $74.6 \%$ & Sufficient \\
\hline & Total & $\begin{array}{c}322.6 \%: 6 \\
=80.65 \%\end{array}$ & Good \\
\hline
\end{tabular}

Table 3 shows that most respondents $(80.65 \%)$ have a good impression towards the ability of video to provide an explanation about the importance of knowledge of Sundanese food in adolescents. This means that as an educational media, Sundanese food graphic videos has been able to provide new knowledge about Sundanese food knowledge, respondents feel that educational videos are important to be learned, respondents feel more interested in learning about Sundanese food through these videos, and these videos make respondents want to develop culture through food. The learning process must contain the principle of effect by showing the benefits obtained after learning something. As an educational medium, Sundanese food educational videos have applied the principle of effect.

\section{Youth Perceptions of Visualization Aspect on Sundanese Food Graphic Video}

Adolescent's perception of visualization aspect on Sundanese food graphic video is the teenagers' impression on the ability of the video to visualize clearly and attractively. This is measured by the ability of the video to show clear material, starting from the display, images, duration, colour selection, background music, and selecting the letters used in video graphics. Following are the results of the frequency distribution of adolescents' perceptions towards visualization aspects in Sundanese food educational video.

TABLE IV. YOUTH PERCEPTIONS OF VISUALIZATION ASPECT ON SUNDANESE FOOD GRAPHIC VIDEO

\begin{tabular}{|c|c|c|c|}
\hline No. & Statement & Percentage & Category \\
\hline 1. & $\begin{array}{l}\text { I really like the appearance of this } \\
\text { Sundanese food educational video }\end{array}$ & $77 \%$ & Good \\
\hline 2. & $\begin{array}{l}\text { The image display on the video is } \\
\text { clear, so I can imagine well the } \\
\text { actual type of food }\end{array}$ & $79 \%$ & Good \\
\hline 3. & $\begin{array}{l}\text { In my opinion, the viewing duration } \\
\text { of the material is not too long nor } \\
\text { boring }\end{array}$ & $79 \%$ & Good \\
\hline 4. & $\begin{array}{l}\text { I think the colour selection on the } \\
\text { video is very good so that the } \\
\text { display of the material can be read } \\
\text { clearly }\end{array}$ & $73 \%$ & Sufficient \\
\hline 5. & $\begin{array}{l}\text { I think the selection of background } \\
\text { music fits perfectly into the video }\end{array}$ & $80 \%$ & Good \\
\hline 6. & $\begin{array}{l}\text { I think the font selection in this } \\
\text { video is good and can be read } \\
\text { clearly }\end{array}$ & $78 \%$ & Good \\
\hline & Total & $\begin{array}{c}466 \%: 6= \\
77.7 \%\end{array}$ & Good \\
\hline
\end{tabular}

Table 4 shows that most $(77.7 \%)$ have a good impression towards the ability of the video to provide visualization in a clear and attractive way. This means that as an educational medium, graphic video of Sundanese food has been able to provide a clear and attractive appearance, image, duration, colour selection, background music, and font selection. 
Graphic video is believed to be an effective medium for delivering information [4]. An audio-visual media (video) is interesting because of the nature of media that can involve the senses of hearing and sight [8], audio-visual media is a medium that involves the senses of hearing and sight simultaneously in one process [9]. Graphic video is a medium to record a moment or event that is summarized in the history of images and sounds that we can enjoy later, either as a prohibition or as a study material to learn what has happened or has happened [10]. With the development of information technology, it makes it easier for all groups to convey and get access to information and knowledge of Sundanese food, especially for adolescents.

With video media, teenagers feel more interested and easier to understand the Sundanese food material that is delivered because they can hear the explanation as well as see first-hand the form, ingredients, and methods of making the Sundanese food. Suggesting audio-visual media is a medium that involves the senses of hearing and sight at the same time in one process [9]. Explaining that audio-visual media is a media that can be heard and seen so that it can convey understanding or information in a more concrete way than what is conveyed orally or written [11].

\section{CONCLUSION}

From the results of research on the perceptions of adolescents in the Department of Family Welfare Education batch 2019 regarding graphic videos of Sundanese food, the following conclusions can be drawn:

- Most of the respondents (77\%) have a good perception towards the attention aspect or the ability of the video in showing teaching materials about Sundanese food.

- More than half of the respondents $(72.6 \%)$ have a good perception towards the needs aspect or the ability of the video in showing the problems faced in an effort to increase knowledge of Sundanese food in adolescents.

- Most of the respondents $(80.65 \%)$ have a good perception towards the ability of the video to explain the importance of knowledge about Sundanese food for adolescents.

- Most of the respondents (77.7\%) have a good perception towards the ability of the video to provide visualization clearly and attractively.
Most of the respondents $(76.9 \%)$ have a good perception towards the capabilities of Sundanese food video graphics. It is hoped that this educational video media will be able to increase adolescent knowledge about Sundanese food. Audio visual media (video) is a medium that is good enough to help the learning process for adolescents. This media can reach a wider range of youth targets by utilizing one of the applications in the new media, namely YouTube. This application has been widely accessed by all groups, thus the educational process through video media is not only consumed by teenagers, but is also able to educate the general public to be interested in learning Sundanese food and traditional Indonesian food.

\section{REFERENCES}

[1] D. Yasminia, Perilaku Konsumen Remaja Terhadap Makanan Tradisional Sunda di Bogor. Bogor: Institut Pertanian Bogor, 2003

[2] C. Yulia and E.E. Nikmawati, "Preliminary Study in Developing Traditional Street Foods as Nutrition Education Media for Indonesia Youth," Jurnal UPI, 2017.

[3] K. Siddhartha, "Consumer perception on Organized Fast Food Retail Outlets towards brand image in Bhopal, IRC's," International Journal of Multidisciplinary Research in Social and Management Sciences, vol. 1, no. 2,2013

[4] S. Barnes, "Studies in the Efficacy of Motion Graphics: How the Presentation of Complex Animation Implicates Exposition," Journal of Entertainment and Media Studies, vol. 2, no. 1, 2016.

[5] A. Firdian, Pengertian Video Grafi [Online]. Retrieved from: http://agus firdian.blogspot.com/2013/06/pengertian-videografi.html, Accessed on: 9 May 2020.

[6] N.W. Syam and D. Sugiana, Perencanaan pesan dan media. Jakarta: Universitas Terbuka, 2007.

[7] E. Daniel, "The Usefulness of Qualitative and Quantitative Approaches and Methods in Researching Problem-Solving Ability in Science Education Curriculum," Journal of Education and Practice, vol. 7, no.15, 2016.

[8] E. Widiyanti and A.I. Santoso, "Persepsi Petani Terhadap Video Penyuluhan Sistem Of Rice Intensification (Sri) Sebagai Media Informasi Pertanian Organik Bagi Petani (Studi Kasus Di Kelompok Tani Bina Lingkungan Kecamatan Andong Kabupaten Boyolali),' Caraka Tani: Journal of Sustainable Agriculture, vol. 31, no. 1, pp. 1-6, 2016

[9] Y. Munandi, Media Pembelajaran. Jakarta: Gaung Persada Press, 2008.

[10] A. Firdian, Pengertian Video Grafi [Online]. Retrieved from: http://agusfirdian.blogspot.com/2013/06/pengertian-videografi.html, Accessed on: 9 May 2020.

[11] D. Daryanto, Media Pembelajaran. Yogyakarta: Gava Media, 2010. 